\title{
Waste Thermal Treatment Installations in Poland
}

\author{
Waldemar KĘPYS ${ }^{1)}$, Katarzyna JASZCZURA ${ }^{2)}$
}

\footnotetext{
1) dr inż.; AGH University of Science and Technology, Faculty of Mining and Geoengineering, Department of Environmental Engineering, Mickiewicza 30, 30-059 Krakow, Poland; email: kepys@agh.edu.pl

2) mgr inż.; Graduate of AGH University of Science and Technology, Faculty of Mining and Geoengineering, Mickiewicza 30, 30-059 Krakow, Poland
}

http://doi.org/10.29227/IM-2020-01-07

Submission date: $29-11-2019$ | Review date: 12-02-2020

Abstract
Waste thermal treatment by incineration, co-incineration, gasification or pyrolysis aims at recovering the waste, mainly in the form
of energy. In addition, it also serves to disposal of waste, in particular hazardous one, including medical and veterinary waste. Ther-
mal treatment of waste should be carried out in specially adapted installations that meet the BAT requirements. The article discusses
installations operating in Poland designed for thermal treatment of municipal solid waste, sewage sludge as well as hazardous waste,
including medical and veterinary waste.

Keywords: thermal waste conversion, installations, incineration, waste co-incineration

\section{Introduction}

One of the waste handling methods is thermal treatmentin installations called incineration and co-incineration plants. Currently, there are over 2,000 waste incineration plants operating worldwide, including approx. 1,200 installations in Japan and almost 500 in Europe [1]. In accordance with the Directive of the European Parliament on the incineration of waste [2], waste incineration plant means any stationary or mobile installation in which waste is incinerated through oxidation. In an incineration plant, waste may also be thermally treated by means of pyrolysis, gasification or plasma process, provided that the substances resulting from the treatment are subsequently incinerated. The operation of co-incineration plants, on the other hand, consists in the generation of energy or products in which waste constitutes an additive to fossil fuels in order to recover the energy contained in it or for waste disposal. Both incineration and co-incineration plants must be equipped with installations and equipment for receiving, preparing and storing waste, conducting a thermal process, cleaning waste gases and discharging them into the air. Other required installations are designed for inspection, control and monitoring of processes as well as storage and processing of substances derived from the combustion and treatment of waste gases. According to the Directive [2], in these installations waste can be recovered (R1 recovery process) and used as a fuel and/or neutralized (D10 disposal process).

The EU Reference Document (BREF) for Best Available Techniques (BAT) for thermal waste treatment [3] distinguishes several types of waste subjected to those processes. These include municipal waste, hazardous waste, sewage sludge and medical waste. On account of the characteristic properties of those types of waste, thermal treatment is carried out in different types of boilers. Decisive factors here include mainly the morphological diversity of waste, physical state, grain composition in the case of solid waste, chemical composition, sanitary and ethical standards.

Regardless of the type of waste and the type of boiler, an important requirement from the point of view of environmental impact is the requirement of maintaining temperature of gases in the combustion chamber. For the incineration of hazardous waste with the content of halogenated organic substances expressed as chlorine above $1 \%$, the temperature of gases must be $\min .1100^{\circ} \mathrm{C}$, for at least two seconds. For other wastes, the temperature of gases must be $\min .850^{\circ} \mathrm{C}$ for two seconds. Another condition of operation is conducting the process in such a way that the total organic carbon content in the slag and bottom ash is lower than $3 \%$ or the loss on ignition when slag and the bottom ash is lower than $5 \%$ of dry matter.

\section{Waste thermal treatment methods}

The thermal treatment of waste consists mainly in its incineration; the pyrolysis and gasification methods are much less frequently used. The incineration itself is a set of fast oxidation reactions of combustible parts contained in waste, which results in the release of heat and light. The products of the process are gases, fly ash and bottom ash (slag). Gasification involves partial oxidation of an organic substance contained in the waste. The gasification product is flammable gas, which can be used as a fuel or raw material, and solid phase in the form of slags and ashes. Pyrolysis, on the other hand, involves thermal degradation of organic matter under anaerobic conditions. Three products are produced in the pyrolysis process: pyrolysis gas, oil and water as well as solid phase in the form of ash and coke [4].

Mixed municipal solid waste (MSW) for purpose of treatment is usually a mixture of various wastes (rubber, foil, hard plastics, fabrics, paper, cardboard, wood, ballast in the form of glass, debris). The heterogeneity in terms of morphological and grain composition caused that grate hearths are most 
Tab. 1. List of municipal solid waste incineration plants in Poland

Tab. 1. Zestawienie instalacji termicznego przekształcania odpadów komunalnych w Polsce

\begin{tabular}{|c|c|c|c|c|c|}
\hline No. & $\begin{array}{c}\text { Installation } \\
\text { location in } \\
\text { Poland }\end{array}$ & $\begin{array}{c}\text { Capacity } \\
{[\mathbf{M g} / \mathbf{y} \text { ear }]}\end{array}$ & $\begin{array}{c}\text { Calorific } \\
\text { value of waste } \\
{[\mathbf{M J} / \mathbf{k g}]}\end{array}$ & $\begin{array}{c}\text { Thermal } \\
\text { power } \\
{[\mathbf{M W}]}\end{array}$ & $\begin{array}{c}\text { Electric power } \\
{\left[\mathbf{M w}_{\mathbf{e}}\right]}\end{array}$ \\
\hline 1 & Kraków & 220000 & 8.8 & 35 & 10.7 \\
\hline 2 & Bydgoszcz & 180000 & 8.5 & 27.7 & 9.2 \\
\hline 3 & Konin & 94000 & 7.8 & 15.5 & 4.4 \\
\hline 4 & Poznań & 210000 & 8.4 & 34 & 15 \\
\hline 5 & Szczecin & 150000 & 10.5 & 32 & 9.4 \\
\hline 6 & Białystok & 120000 & 7.5 & 17.5 & 6.1 \\
\hline 7 & Warszawa & 40000 & 10.1 & 9.1 & 1.4 \\
\hline 8 & Rzeszów & 100000 & 8.0 & 16.5 & 4.6 \\
\hline & Total & 1114000 & - & 187.3 & 60.8 \\
\hline
\end{tabular}

often used. This enables the waste to be mixed and moved on the grate and the exhaust gases to be burned in the chamber above it.

MSW is also processed into a full-fledged fuel by separating combustible fractions from it, shredding and drying. The resulting homogeneous mixture with averaged properties is most often referred to as refuse derived fuel (RDF). It can be easily transported and stored and does not pose a threat to the environment or people. The main recipients of RDF in Poland are cement plants, which use it to burn clinker in the process of co-incineration with coal in a cement kiln. Heating and power plants can be other recipients.

In installations dedicated to the thermal treatment of sewage sludge, fluidized bed boiler are most often used. This is primarily due to the high degree of fragmentation of waste, homogeneous grain and chemical composition. Fermented sewage sludge, after dehydration, is pre-dried to $30-35 \%$ of dry matter content. This is necessary to reduce the water content in the sludge, and thus obtain autothermal or near-autothermal conditions during combustion. Thermal energy for drying is recovered from flue gas. An example of sludge combustion technology is PYROFLUIDTM. Another way of burning sewage sludge in Poland is combustion in grate boilers. Before feeding to the boiler, sewage sludge is dried to a content of approx. $90 \%$ of dry matter. An example of such technology is the BIOCON ${ }^{\circledR}$ system.

In turn, hazardous waste may occur in various forms (solid, gas, liquid or paste). In addition, it is characterized by variable calorific value and chemical composition (can contain significant amounts of chlorine). Hence, rotary kilns are most commonly used for thermal treatment [5]. Their basic advantage is that they can be equipped with several dispensers enabling feeding waste to the boiler regardless of the form: loose, by pumping or in containers in which they were delivered to the installation. In addition, such installations very often have a feeder adapted to the administration of medical and veterinary waste.

\section{Installations in Poland Municipal solid waste}

There are currently 8 municipal solid waste incineration plants in Poland with a total capacity of 1.1 million $\mathrm{Mg} /$ year (Tab. 1.). In 2018, approx. 12.5 million Mg of MSW was gen- erated in Poland, of which 3 million Mg underwent thermal treatment [6]. It follows that about $8.8 \%$ of MSW was incinerated in 8 installations. Incineration takes place on a mechanical grate. In addition, all installations are equipped with facilities to recover waste and produce electricity and heat from it. The total thermal power of the installation is over $187 \mathrm{MWt}$, while the electric power is $60.8 \mathrm{MWt}$. Installations may accept mixed municipal solid waste for incineration (waste code 2003 01) and a selected fraction - RDF fuel (waste code 1912 12 ), whose average share is $40 \%$ [1].

Municipal solid waste also serves to produce alternative fuel (waste code 1912 10) which is used in the process of co-incineration. In addition to the listed MSW incineration plants, the Zabrze heat and power plant, equipped with a circulating fluidised bed boiler, in which refuse derived fuel (about $250000 \mathrm{Mg} /$ year) is being co-incinerated together with coal and biomass, was opened in 2018. The capacity of the installation is $225 \mathrm{MW}$ of fuel input (thermal power: 145 MW, electric power: $75 \mathrm{MW}$ ). The assumed annual heat production is $730 \mathrm{GWh}$ and the annual electricity production is 550 GWh [7].

Alternative fuel from MSW is also used as a substitute for coal in cement plants for the production of clinker. In addition, other types of waste, such as tyres, sewage sludge or meat and bone meal as well as biomass (agricultural and forest biomasses) are co-incinerated in cement plants. The use of waste in cement plants is considered as energy recovery (process R1) and raw material recovery (process R5) because ash is a component of clinker. There are 10 cement plants using alternative fuel in Poland, with cement production capacity of approx. 22 million $\mathrm{Mg} /$ year. The average share of heat from alternative fuels in Polish cement plants reaches $70 \%$, while in some cement plants it reaches $80 \%$ [8]. In 2015, approx. 1.4 million Mg of alternative fuel was used, including approx. 1.1 million $\mathrm{Mg}$ of refuse derived fuel (RDF). It is estimated that in 2020 the demand for alternative fuel will be approx. 1.8 million $\mathrm{Mg}$, of which 1.5 million $\mathrm{Mg}$ will be the combustible fraction of municipal solid waste [8].

\section{Sewage sludge}

There are 11 installations for the thermal treatment of sewage sludge in Poland (Tab. 2), whose capacity ranges from 1 
Tab. 2. List of sewage sludge mono-incineration plants in Poland

Tab. 2. Zestawienie monospalarni osadów ściekowych w Polsce

\begin{tabular}{|c|c|c|c|}
\hline No. & $\begin{array}{c}\text { Location of the } \\
\text { incineration plant }\end{array}$ & $\begin{array}{c}\text { Capacity Mg of } \\
\text { dry matter/year } \\
{[9]}\end{array}$ & Type of boiler \\
\hline 1 & Warszawa & 62.2 & fluidised \\
\hline 2 & Kraków & 23.0 & fluidised \\
\hline 3 & Łódź & 21.0 & fluidised \\
\hline 4 & Gdańsk & 14.0 & fluidised \\
\hline 5 & Gdynia & 9.0 & fluidised \\
\hline 6 & Bydgoszcz & 10.0 & fluidised \\
\hline 7 & Szczecin & 6.0 & mechanical grate \\
\hline 8 & Zielona Góra & 6.4 & mechanical grate \\
\hline 9 & Kielce & 6.2 & fluidised \\
\hline 10 & Olsztyn & 3.2 & mechanical grate \\
\hline 11 & Lomża & 1.5 & mechanical grate \\
\hline & Total & 162.5 & \\
\hline
\end{tabular}

Tab. 3. List of installations for the thermal treatment of hazardous waste in Poland Tab. 3. Zestawienie instalacji termicznego przekształcania odpadów niebezpiecznych w Polsce

\begin{tabular}{|c|c|c|}
\hline Type of waste incinerated & $\begin{array}{c}\text { Number of } \\
\text { installations in } \\
\text { Poland }\end{array}$ & $\begin{array}{c}\text { Capacity } \\
\text { [Mg/year] }\end{array}$ \\
\hline Hazardous waste & 20 & 370,663 \\
\hline Medical and veterinary waste & 18 & 80144 \\
\hline Total & 38 & 450807 \\
\hline
\end{tabular}

500 to $62200 \mathrm{Mg}$ of dry matter/year [9]. Total capacity is more than $162000 \mathrm{Mg}$ of dry mass/year. Fermented, dehydrated and dried sludge is incinerated in fluidised bed boilers (7 installations) or on mechanical grate (4 installations). These are called mono-incineration plants, as they incinerate sewage sludge only. In addition, sewage sludge is incinerated in hazardous waste incineration installations. It may also be co-incinerated in cement plants, although the problems that arise due to low calorific value of sediments, phosphorus content (negative effect on strength parameters of cement) and chlorine (increased risk of corrosion) should be taken into account [9].

\section{Hazardous waste}

Hazardous waste, including medical and veterinary waste, is incinerated in several dozen installations. According to the data contained in the Voivodeship Waste Management Plans, a total of 38 such installations operate in Poland (Tab. 3). These installations have a various capacity (total capacity is over 450 thousand $\mathrm{Mg}$ /year), incorporating various types of boilers. They are mainly used for the disposal of hazardous and non-hazardous waste (process D10), with energy recovery (process R1). They include installations which provide commercial services (with capacity of up to $80,000 \mathrm{Mg} /$ year) incinerating hazardous waste, including medical, veterinary and non-hazardous waste (incineration of up to approx. 1000 different types of waste). In addition, there are installations operating next to the plants, often dedicated to one type of waste, generated in a given plant (chemical, petrochemical or processing of animal products). The second group are installations dedicated to medical and veterinary waste. These are installations that collect waste from healthcare facilities, laboratories, veterinary establishments or small installations that operate next to hospitals. Their capacity ranges from $200 \mathrm{Mg}$ / year to $10000 \mathrm{Mg} /$ year.

\section{Summary}

The primary form of waste management should be the reuse and recycling of waste. Thermal treatment of waste in Poland is one of the methods of waste management. It mainly enables the recovery of energy and raw materials, as well as waste disposal, which is particularly important for hazardous waste, including medical and veterinary waste. A total of 68 installations for thermal treatment of waste operate in Poland. They include 8 municipal solid waste incineration plants, 11 plants for the co-incineration of alternative fuel from municipal solid waste ( 10 cement plants and 1 heat and power plant), and 11 sewage sludge mono-incineration plants. In addition, hazardous waste incineration plants are in operation - 38 installations, including 18 installations incinerating medical waste only.

\section{Acknowledgement}

The article was developed as part of the AGH subsidy No. 16.16.100.215. 


\section{Literatura - References}

1. Wielgosiński G., Czerwińska J., 2019. Spalarnie odpadów komunalnych w Polsce. Nowa Energia, nr 4.

2. Directive 2000/76/Ec of the European Parliament and of the Council of 4 December 2000 on the incineration of waste.

3. European Commission, Integrated Pollution Prevention and Control, 2019. Reference Document on the Best Available Techniques for Waste Incineration.

4. Lapčik V., Lapčik V. jr., Čablik V, 2018. Energy Recovery from Municipal and Other Waste. Inżynieria Mineralna/ Journal of the Polish Mineral Engineering Society, R. 42, nr 1, pp. 265-272.

5. Kępys, W., Wisła-Walsh, E. , Matusik, J., 2018. Chemical examination of fly ash and bottom ash derived from incineration of hazardous waste. Inżynieria Mineralna/Journal of the Polish Mineral Engineering Society, R 19, nr 1, pp. 21-233.

6. Główny Urząd Statystyczny, 2019. Ochrona środowiska 2019. Warszawa.

7. http://www.eczabrze.fortum.pl/

8. Środa B., 2018. Paliwa alternatywne w przemyśle cementowym - aktualne wyzwania. Budownictwo - technologie architektura, Wyd. 3(83), str. 68-71.

9. Ministerstwo Środowiska, 2018. Strategia postępowania z komunalnymi osadami ściekowymi na lata 2019-2022. Warszawa.

\section{Instalacje termicznego przekształcania odpadów w Polsce}

Termiczne przekształcenie odpadów poprzez spalanie, wspótspalanie, zgazowanie czy pirolizę ma na celu ich odzysk, głównie energii. Ponadto służy także unieszkodliwieniu odpadów, w szczególności odpadów niebezpiecznych, w tym odpadów medycznych $i$ weterynaryjnych. Termiczne przekształcanie odpadów powinno być prowadzone w specjalnie do tego przystosowanych instalacjach, spetniających wymagania BAT. W artykule omówiono instalacje funkcjonujące w Polsce dedykowane do termicznego przekształcania odpadów komunalnych, osadów ściekowych, odpadów niebezpiecznych w tym medycznych i weterynaryjnych.

Słowa kluczowe: termiczne przekształcanie odpadów, instalacje, spalanie, wspótspalanie odpadów 